\title{
KIRJOITUS
}

TUULA VASKILAMPI

\section{Postmoderni kuolema}

Y

hteiskunta pyrkii takaamaan elämän jatkuvuuden. Kuolema uhkaa olemassaolollaan arjen ennustettavuuden. Kukin aikakausi synnyttää omat kulttuuriset kuoleman selityksensä ja rituaalinsa, jotka ilmentävät vallitsevaa kulttuuria ja yhteiskunnan rakennetta.

\section{Moderni ja postmoderni aikamme}

Elämme nyt aikaa, jota hallitsee yhä voimakkaammin teknistieteellisen maailmankuva. Rationaalisuus ja tehokkuus ovat nousseet keskeisiksi arvoiksi, joilla pyritään saamaan elämä hallintaan. Tässä maailmassa Ihminen on siirtynyt kaiken keskipisteeksi. Hänen tavoitteenaan on hallita omaa elämäänsä: kehoa ja luontoa - olla sekä oman elämänsä että koko luomakunnan herra. Hän pyrkii ymmärtämään tämän puoleisen maailman lisäksi myös tuonpuoleisen oman itsensä kautta. Modernin yhteiskunnan erityispiirteet ovat pääosin edelleen voimissaan, kuitenkin sen rinnalle on nousemassa postmodernin kulttuuri. Se on vastakulttuuri, joka on kääntänyt katseensa menneisyyteen ja yksilön sisäiseen maailmaan. Siinä totuus käsitteellistetään relatiivisena, jolloin jopa vastakkaiset totuudet voivat olla voimassa samanaikaisesti. (Gellner, 1992.) Lisäksi ajallemme on tyypillistä, että reaalitodellisuuden rinnalle on yhä voimakkaammin nousemassa virtuaalitodellisuus.

\section{Kuoleman kulttuurin historialliset juuret}

Esiteollisena aikana ihminen eli luonnon armoilla. Luonto antoi elämälle rajat ja kuolema oli osa näkyvää arkea. Kuolemaa hallittiin rituaalein, jotka perus- 
tuivat yhteisiin ja pääosin uskonnollisiin symboleihin - näin tuonpuoleinen maailma sai selityksensä. Tämänpuoleinen ja tuonpuoleinen maailma olivat toistensa kanssa vierekkäin ja limittäen arjessa. Kuolema voitiin ivallisesti haastaa myös vuoropuheluun groteskilla ja rienaavalla huumorilla sekä ilveilijöiden tansseilla: kuoleman tansseilla. Näin yritettiin kesyttää pelottava vastapeluri. Kuoleman tansseista on meille säilynyt keskiaikaisia runoja ja maalauksia. (ks. Bakhtin, 1995.)

Elämme nyt modernia ja postmodernia aikaa, jolloin yhtenäinen ja koko yhteiskuntaamme kattava kulttuuri on pirstoutunut erillisiksi saarekkeiksi. Toiset ihmiset pyrkivät säilyttämään tai löytämään uudelleen perinteiset merkitykset ja symbolit ja toiset ovat yhdistelleet fragmentteja eri kulttuureista. Lisäksi tieteellistekninen ajattelu on levinnyt eri tavoin eri yhteiskuntaryhmissä. Kulttuurin moninaisuus heijastuu myös uskontojen moninaisuudessa.

\section{Kuoleman markkinat}

Kuolema käsitteessä ei enää voida havaita varsinaisesti yhtenäistä ja kaiken kattavaa kulttuurista megatrendiä. Kuitenkin yhtenäisinä kulttuurin piirteitä on erotettavissa individuaalisuuden, teknisyyden, rationaalisuuden ja tehokkuuden arvot. Voidaan väittää, että tiede on ottanut uskonnon paikan aikamme arvoperustassa. Kuoleman kulttuureissa on havaittavissa juuri näitä samoja yleisen kulttuurin piirteitä. Kuitenkin kuolema haastaa edelleen tieteen kaikkivoipaisuuden ja ihmisen kyvyn elämän hallintaan.

Kuoleman käsittely on yhä enenevässä määrin muuttunut individuaaliksi ja siirtynyt yhteiskunnan ja varsinkin sen terveydenhuollon hallintaan perheen ja kirkon jäädessä sivuun. Ajassamme on muotoutumassa uudenlaisia kuoleman instituutioita ja vanhat instituutiot ovat sisällöiltään muuttumassa. Niiden symbolinen valta toimia siirtymäriittinä joutuvat testattaviksi. Voidaankin kysyä, ovatko ne todella toimivia ja uskottavia? (ks. esim. Peräkylä, 1986).

Tuskin koskaan aikaisemmin kuolevat ja heidän auttajansa ovat tulleet niin erilaisista alakulttuureista, tuskin koskaan he ovat olleet yhtä avuttomina käsittämättömän edessä kuin nykyisin. Kristillinen usko tarjoaa opissaan selitykset ja toimintamallit niin elämään kuin kuolemaankin ulottuen aina tuonpuoleiseen saakka. Niissä on yhteinen perusta. Kuitenkin ne poikkeavat yksityiskohdissa toisistaan: Esimerkiksi ortodoksikirkossa hautajaisissa pidetään vainajan arkunkansi avoimena ja surevat omaiset jättävät niin konkreettisesti 
kuin symbolisesti hyvästit vainajalle. Siinä kohdataan kuolema reaalisena, voimakkaammin kuin muissa kristillisissä uskontokunnissa. Roomalaiskatollisessa kirkossa vastaavasti kuolevan potilaan papilta saama viimeinen voitelu on tärkeä. Luterilaisuudessa arvostetaan ehtoollisen nauttimista viime hetkillä.

Monet maailman uskonnot tarjoavat vastaavasti omien oppiensa mukaiset suuret kertomukset, maailman selitysmallit, jotka sisältävät niin elämän kuin kuoleman. Postmodernin ajan ihmiset ovat ottaneet fragmentteja luonnonuskontojen käsitejärjestelmistä, esimerkiksi uusshamanismista. Aikamme ihmisillä myös vallitsee erilaisia maallisia käsityksiä ja arjen toimintamalleja, jotka ovat vailla yhteyttä tuonpuoleiseen ja keskittyvät vain tämänpuoleiseen arkeen: perheeseen, elämän saavutuksiin, suvun jatkumiseen ja yhteisöllisyyteen. Tällöin kuoleman hallintaan etsitään turvaa arjen jatkuvuudesta.

Aikamme ihmisillä ovat yleistyneet myös vaatimukset eutanasiaan laillistamiseksi, joka antaa teknishallinnollisen keinon päättää oman kuoleman ajankohdan (Vaskilampi, 2013).

Postmodernina aikana kuoleman markkinat ovat monimuotoistuneet.

\section{Postmoderni kuolema}

Postmoderni kuolema on siirtynyt reaalitodellisuuden ulkopuolelle ja äärimuodossaan virtualisoitunut. Viime aikoina virtuaalimaailma on tarjonnut jopa mahdollisuuden virtuaalisiin hautajaisiin. Postmoderni kuolema on toisin sanoen samanaikaisesti sekä reaalimaailmassa että virtuaalitodellisuudessa. Voidaan myös väittää, että kuolema on kuitenkin samalla arkipäiväistynyt. Siitä on hävinnyt pyhän kosketus ja juhlallinen kunnioitus. Kuolema on muuttunut näkymättömäksi ja vieraaksi elämälle. Toisaalta individualisoitumisen ohella on voimistunut kollektiivinen kuoleman kohtaaminen ja ilmentäminen. Tämä näkyy viihdeteollisuudessa ja surun osoittamisessa tapaturmien uhreille sekä julkisten kuoleman yhteydessä. Nykyisin halutaan tuoda julkisille paikoille muistoesineitä ja kukkia. Hautausmailla kynttilöiden polttaminen juhlapyhinä on lisääntynyt voimakkaasti viime vuosikymmeninä. Ihminen on aina tarvinnut tuntemattoman edessä siirtymäriittejä, joilla on kyky ja uskottavuus siirtää hänet toiseen todellisuuteen. Mitä ja millä tavoin tiedettä ja tehokkuuttamme arvostava aikamme kohtaa nämä haasteet, jotka tulevat jokaisen kohdalle? 
Yhtenä vastauksena aikamme ihmiset ovat siirtäneet kuoleman käsittelyn yhä enenemässä määrin terveydenhuollolle ja muille yhteiskunnallisille toimijoille (viranomaisille). Terveydenhuollon sisällä on vastaavasti pyritty siirtämään kuoleman käsitteellisesti ja toiminnallisesti näkymättömäksi erilleen muusta hoidosta: keskustelussakin on siirrytty saattohoitoon ja eutanasiaan. (Vaskilampi, 2013.) Näin kuolema muuntuu yhä enemmän hallinnolliseksi ja puhtaasti tekniseksi kysymykseksi. Illich (1974) klassisessa kirjassaan Medical Nemesis kritisoi sitä, kuinka kohtaamme nykyisin kärsimyksen, kivun ja kuoleman tainnutettuina lääkehumalaan; tajunta ja aistit turrutettuina. Hänen mukaansa koko voimakkaasti kasvanut terveysteollisuus saa käyttövoimansa käsittelemättömästä kuoleman pelosta. Poikkeuksena tälle on sairaalateologian toiminta-alue, joka perustuu kristilliseen henkissielulliseen ihmiskäsitykseen. Lisäksi saattajan ja saatettavan kokema keskinäinen rakkaus pystyy ylittämään elävistä symboleista tyhjentyneet riitit ja antamaan voimaa kuoleman kohtaamiseen.

Myös hautajaisten muuttuminen heijastaa kulttuurin muuttumista. Polttohautaukset ovat lisääntyneet voimakkaasti viimeisten parin kolmen vuosikymmenen aikana. Kun hautaan laskettava ruumis muuttuu hitaasti osaksi luomakunnan kiertoa - osaksi luontoa, niin tuhkattu ruumis hajoaa savuna ilmaan. Se katoaa tyhjyyteen. Tuhkaus on tehokasta, siistiä, edullista ja nopeaa vallitsevan modernin ajan hengen mukaisesti. Vastaavasti voidaan tulkita, että tuhkaus siirtää vainajan kevyesti pois näyttämöltä näkymättömiin ja että itse tuhkaus siirtää helposti saattajat virtuaalinomaiseen todellisuuteen. Voiko tulevaisuudessa reaali- ja virtuaalimaailma sekoittua yhä voimakkaammin keskenään? Muuttuuko silloin postmoderni kuolema olemukseltaan kokonaan virtuaaliseksi?

Muistotilaisuudet ja suruaika pyritään myös hoitamaan nopeasti ja tehokkaasti. Tärkeintä on nopea paluu arjen rutiineihin.

Tekniset innovaatiot ja ulkokohtaiset viranomaisten ohjeistukset eivät pysty takaamaan ihmisen arvoista vierellä kulkemista tuntemattoman edessä. Majesteetin, jonka syvin olemus on ja pysyy mysteerinä. 


\section{Kirjallisuus}

Gellner, E. (1992). Postmodermism, Reason and Religion. London \& New York: Routledge. Illich, I. (1975). Medical Nemesis. London: Calder \& Byars.

Bahtin, M. (1955). François Rabelais: Keskiajan ja renessanssin nauru. Helsinki: Taifuuni.
Peräkylä, A. (1986). Kuoleman symboliikka. - K. Eskola (toim) Symbolit. Jyväskylän yliopisto, Nykykulttuurin tutkimuskeskus, 97-109.

Vaskilampi, T. (2013). Eutanasian sosiaalinen ulottuvuus. Lääkärilehti, 15/2013, 10821083. 